\title{
ANALISIS PENAFSIRAN FAZLURRAHMAN DAN MASDAR F. MAS'UDI TENTANG ZAKAT DAN PAJAK
}

\author{
Umniyatis Sholihah Hastriana \\ Sekolah Teknik Malang \\ neng.umni@gmail.com
}

\begin{abstract}
Abstrak
Zakat merupakan kewajiban bagi umat Islam yang ditegaskan dalam alQur'an. Zakat termasuk pula dari rukun Islam. Namun, umat Islam selain berkewajiban membayar zakat, berkewajiban pula membayar pajak. Zakat perintah dalam Islam yang wajib ditunaikan, sedangkan pajak merupakan ketentuan Undang-Undang yang wajib dipatuhi sebagai warga Negara yang baik. Karena itu, muncul pemikiran tentang hukum dua kewajiban membayar zakat dan pajak sekaligus bagi umat Islam. Menurut Fazlurrahman, zakat adalah pajak. Artinya, sistem perpajakan harus dimasukkan ke dalam naungan zakat dengan mengubah strukturnya karena hanya zakat yang ditetapkan sebagai pajak dalam al-Qur'an. Sedangkan menurut Masdar F. Mas'udi, zakat adalah ruh dari pajak. Jadi, apabila seseorang meniatkan membayar zakat ketika mengeluarkan pajak, maka orang tersebut sudah dikatakan membayar zakat. Selain itu, membayar dua kewajiban bagi seorang muslim sangat memberatkan dan tidak mencerminkan nilai kemaslahatan.
\end{abstract}

Kata Kunci: Zakat, Pajak, Fąlur Rahman, dan Masdar F Mas'udi.

\section{PENDAHULUAN}

Zakat merupakan salah satu kewajiban umat Islam, sebagaimana tersebut dalam rukun Islam yang keempat. Zakat menjadi sumber dana bagi kesejahteraan umat terutama untuk mengentaskan dari kemiskinan dan menghilangkan kesenjangan sosial. Dalam al-Quran terdapat 32 ayat zakat dan 82 kali diulang dengan mengunakan istilah yang merupakan sinonim dari kata zakat, yaitu kata 
sedekah dan infak. Pengulangan tersebut mengandung maksud bahwa zakat mempunyai kedudukan, fungsi dan peranan yang sangat penting dalam Islam. ${ }^{1}$

Pada masa Rasulullah SAW, Khalifah Abu Bakar ibn Khattab dan Umar ibn Affan, zakat dikelola oleh Negara. Kemudian seiring perkembangan wilayah Islam diberlakukan sistem pajak yangdisebut dengan jizyah yang pada mulanya hanya diberlakukan kepada kalangannon muslim atas jaminan yang mereka terima dari negara.Kemudian seiring perkembangan wilayah Islam diberlakukan sistem pajak yang disebut dengan jizyah yang pada mulanya hanya diberlakukan kepada kalangannon muslim atas jaminan yang mereka terima dari negara. Begitu pula tanah-tanah hasil penaklukkan dengan perjanjian damai yang tetapdianggap milik penduduk setempat namun konsekuensinya mereka diwajibkan membayar pajak (kharaj), bahkan sekalipun pemiliknya telah memeluk ajaran Islam. Inilah kiranya yang menjadi awal berlakunya pajak bagikaum muslimin di luar zakat.

Dalam perkembangannya, menurut $\mathrm{Ali}^{2}$ zakat dan pajak merupakan salah satupersoalan yang banyak mendapat perhatian dalam khazanah pemikiran ekonomiIslam. Persoalan ini muncul karena adanya dua kewajiban yang harus dijalankanoleh umat Islam, yaitu kewajiban membayar pajak sebagai kewajiban seorang warga negara terhadap negaranya, dan kewajiban zakat yang merupakan perintahagama dan salah satu rukun Islam.

Berbeda dengan Negara yang memiliki penduduk mayoritas muslim yang mengenal bahwa zakat adalah pajak yang disahkan dalam al-Qur'an, namun kenyataannya, zakat tidak dapat memberikan kontribusi secara maksimal dalam kebijakan fiskal Negara untuk kesejahteraan rakyatnya. Oleh karenanya, atas dasar ini, Fazlur Rahman mereformulasikan "zakat sebagai pajak", sedangkan Masdar F. Mas'udi "pajak itu zakat". Dari latar belakang masalah tersebut, maka dalam hlm. 43 .

1 Abdurrachman Qadir, 2001. Zakat Dalam Dimensi Mabdah dan Sosial. Jakarta: Raja Grafindo Persada,

${ }^{2}$ Nuruddin Mhd. Ali, 2006. Zakat Sebagai Instrument dalam Kebijakan Fiskal. Jakarta: PT Raja Grafindo Persada, hlm. 23. 
makalah ini akan mengkaji lebih jauh tentang pemikiran Fazlur Rahman dan Masdar F. Mas'udi tentang zakat dan pajak.

\section{DEFINISI ZAKAT DAN PAJAK}

Zakat adalah salah satu pilar penting dalam ajaran Islam. Secara etimologis, zakat memiliki arti kata berkembang (an-namaa), mensucikan (at-thaharatu) dan berkah (albarakatu). Sedangkan secara terminologis, zakat mempunyai arti mengeluarkan sebagian harta dengan persyaratan tertentu untuk diberikan kepada kelompok tertentu (Mustabik) dengan persyaratan tertentu pula. ${ }^{3}$ Pajak berasal dari bahasa latin taxo; rate yang berarti iuran rakyat kepada Negara berdasarkan undangundang, sehingga dapat dipaksakan dengan tidak mendapat balas jasa secara langsung. Menurut Charles E. McLure, yang dikutip oleh wikipedia, pajak adalah kewajiban finansial atau retribusi yang dikenakan terhadap wajib pajak (orang pribadi atau badan) oleh negara yang digunakan untuk membiayai berbagai macam pengeluaran publik.

\section{METODE PENAFSIRAN FAZLUR RAHMAN DAN MASDAR F. MAS'UDI}

\section{Double Movement : Metode Penafsiran Fazlur Rahman}

Menurut Saenong, ${ }^{4}$ Fazlur Rahman dalam hal merumuskan sebuah metode penafsiran al-Qur'an yang lebih tepat dan memadai melalui konformitas-konformitas dan deformitas-deformitas Islam historis bisa dinilai, pada saat yang sama. Metode penafsiran tersebut diharapkan mampu merumuskan nilai-nilai umum dari al-Qur'an yang dapat menjadi panduan bagi umat Islam dalam merespon modernitas. Metode yang digunakan Fazlur Rahman mengenai penetapan zakat sebagai pajak di

3 Refky Fielnanda,. "Zakat Saham Dalam Sistem Ekonomi Islam (Kajian Atas Pemikiran Yusuf Qardhawi)." Al-Tijary: Jurnal Ekonomi dan Bisnis Islam 3.1 (2018): 57-67.

${ }^{4}$ Ilham B. Saenong, 2002.Hermeneutika Pembebasan Metodologi Tafsir Al-Qur'an menurut Hassan Hanafi. Jakarta Selatan: TERAJU, hlm. 3. 
Pakistan yaitu dengan metode double movement. Metode ini terdiri dari dua gerakan yang pada dasarnya merupakan penjabaran dari tiga pendekatan pemahaman dan penafsiran al-Qur'an, yakni pendekatan historis, kontekstual dan sosiologis. Yang mana gerakan ini lebih dikhususkan terhadap ayat-ayat hukum. Selain itu juga metode ini bisa dilakukan dengan membawa problem-problem umat (sosial) untuk dicarikan solusinya pada al-Qur'an atau memaknai al-Qur'an dalam konteksnya dan memproyeksikannya kepada situasi sekarang. Dua gerakan tersebut mempunyai ide berpikir dari khusus kepada yang umum (induktif) dan metode berpikir dari yang umum kepada yang khusus (deduktif).

Metodologi Fazlur Rahman, menurut Esack $^{5}$ dapat diilustrasikan sebagai berikut:

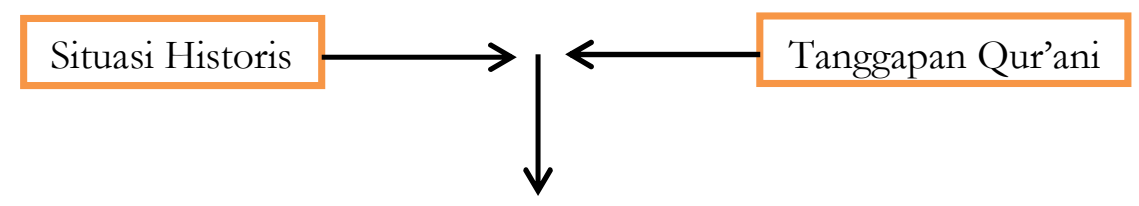

Generalisasi Jawaban Spesifik

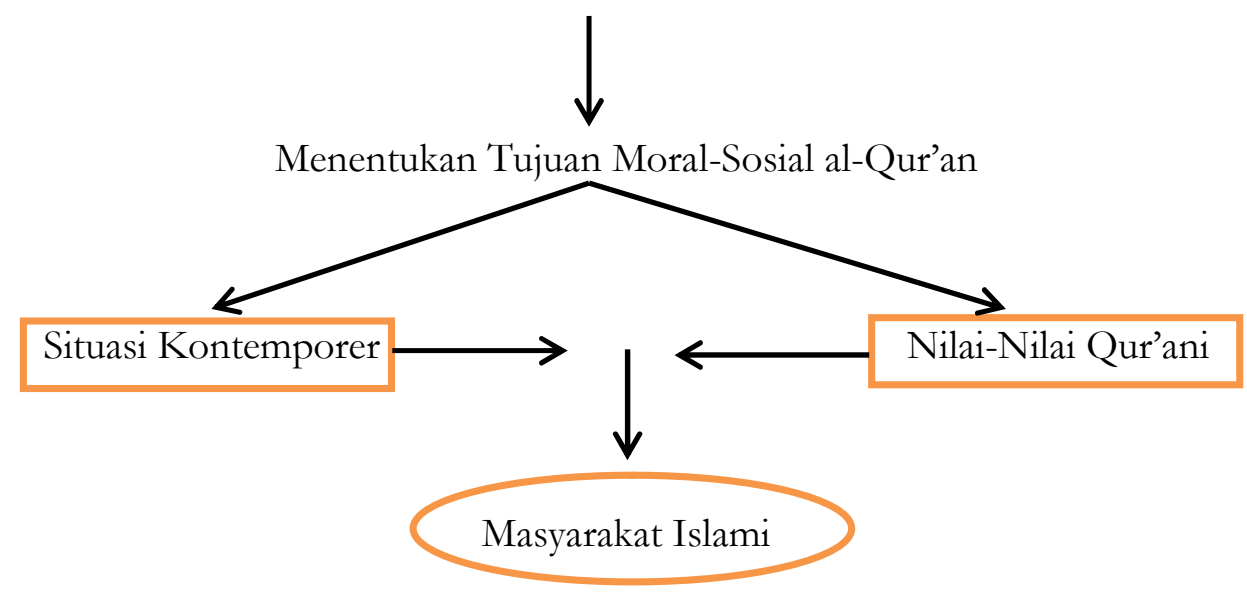


a. Gerakan pertama dari metode double movement.

Metode yang pertama berpikir dari ayat-ayat spesifik menuju prinsip atau dengan kata lain adalah berpikir dari aturan-aturan legal spesifik menuju moral sosial yang bersifat umum yang terkandung di dalamnya.Rumusan gerakan pertama ini diungkapkannya sebagai berikut:

Langkah pertama, orang harus memahami arti atau makna suatu pernyataan (ayat) dengan mengkaji situasi atau problema historis di mana pernyataan al-Qur'an tersebut merupakan jawabannya. Tentu saja sebelum mengkaji ayat-ayat spesifik dari situasi-situasi spesifiknya, suatu kajian situasi makro dalam batasan-batasan masyarakat, agama, adat-istiadat, lembaga bahkan seluruh kehidupan masyarakat di Arab pada saat Islam datang dan khususnya di Mekkah dan di sekitarnya, harus dilakukan terlebih dahulu. Langkah kedua, adalah mengeralisasikan respon-respon spesifik tersebut dan menyatakannya sebagai ungkapan-ungkapan yang memiliki tujuan moral sosial umum, yang dapat disaring dari ungkapan ayat-ayat spesifik dalam sinar latar belakang sosiohistoris dan dalam sinar "rationes leges" (illat Hukum) yag sering digunakan. Benarlah langkah pertama yaitu memahami makna dari suatu pernyataan spesifik_-sudah memperlihatkan ke arah langkah kedua_dan membawa kepadanya. Selama proses ini, perhatian harus ditujukan kepada ajaran al-Qur'an sebagai suatu keseluruhan sehingga setiap arti tertentu yang dipahami, setiap hukum yang dinyatakan, dan setiap tujuan yang dirumuskan akan koheren dengan yang lainnya. Al-Qur'an sendiri mendakwahkan secara pasti bahwa "ajaran tidak mengandung kontradiksi", melainkan koheren dengan keseluruhannya. ${ }^{6}$

Dalam gerakan pertama ini berikut tahapan kerjanya sesuai dengan gambar dan pernyataannya di atas:

1. Pertama adalah memahami al-Qur'an sebagai keseluruhan dan lewat perintah dan ketetapan khusus yang diturunkan sebagai respon pada situasi tertentu. Dalam hal ini dilakukan dengan dua tahap

${ }^{6}$ Fazlur Rahman. Toward Reformulating the Methodology of Islamic Law. International and Politic, Vol. 12, 1979, hlm. 221. 
antara lain: tahap pertama, menjelaskan terhadap situasi historis dan tuntutan moral etisnya, mendahului kajian atas teks-teks alQur'an dalam situasi spesifik. Tahap kedua, menjelaskan tentang menggeneralisasi jawaban-jawaban spesifik itu dan membingkainya sebagai pernyataan tentang tujuan moral sosial umum. Hal ini dapat diperoleh dari teks-teks spesifik dengan melihat latar belakang sosio historisnya, terhadap alasan-alasan yang sering muncul di belakang pemberlakuan hukum-hukumnya. Seperti pada kehidupan aktual yang sedang berkembang dalam segala aspeknya; ekonomi, politik, budaya, dan lain sebagainya.

2. Kedua adalah menerapkan tujuan umum yang telah diperoleh dari pergerakan pertama ke dalam konteks sosio historis konkret masa itu. Penerapan tersebut membutuhkan kajian tentang situasi masa lalu untuk mengubahnya dan menetapkan prioritas bagi menyegarkan implementasi nilai-nilai al-Qur'an. Bersamaan dengan itu, ajaran al-Qur'an harus dipahami sebagai suatu keseluruhan, sehingga setiap arti yang dipahami, setiap hukum yang dinyatakan dan setiap tujaun yang dirumuskan akan saling koheren satu sama lainnya. Fazlur Rahman menggunakan tiga perangkat 'illat al-bukm (ratio logis) yang dinyatakan al-Qur'an secara eksplisit. Kedua, illat al-hukm yang dinyatakan secara implisit dengan menggenaralisasikan beberapa ungkapan spesifik yang terkait. Ketiga, perangkat sosio historis untuk menguatkan illat albukm implisit dalam rangka menetapkan arah, maksud dan tujuannya, sekaligus membantu mengungkapkan illat al-hukm yang sama sekali tidak dinyatakan.

b. Gerakan kedua dari metode double movement.

Metode berpikir ini dari yang umum kepada yang khusus, upaya merumuskan prinsip-prinsip umum, nilai-nilai dan tujuan al-qur'an 
yang telah disistematisasikan melalui gerakan pertama terhadap situasi dan kasus aktual sekarang. Rumusan gerakan kedua ini dinyatakannya (1987) sebagai berikut:

Gerakan kedua harus dilakukan dari pandangan umum yaitu yang telah disistemtiskan melalui gerakan pertama menjadi pandanganpandangan spesifik yang harus dirumuskan dan direalisasikan sekarang ini. Artinya, ajaran-ajaran yang bersifat umum tersebut harus dirumuskan dalam konteks sosio-historis yang konkrit sekarang ini. Sekali lagi, kerja ini memerlukan kajian yang cermat atau situasi sekarang dan analisis berbagai unsur komponennya, sehingga kita dapat menilai situasi sekarang yang diperlukan dan menentukan prioritas-prioritas baru untuk bisa menerapkan nilainilai al-Qur'an secara baru pula.

Gerakan kedua ini terdapat dua kerja yang saling berkaitan. Pertama adalah kerja merumuskan prinsip umum al-Qur'an menjadi rumusan-rumusan spesifik, maksudnya yang berkaitan dengan tematema khusus, misalnya prinsip ekonomi qurani; prinsip demokrasi qurani; prinsip hak-hak asasi qurani dan lain-lain. Di mana rumusan prinsip-prinsip tersebut harus mempertimbangkan konteks sosiohistoris yang konkrit, dan bukan rumusan spekulatif yang mengawang-awang, kerja pertama tidak mungkin terlaksana kecuali disertai kerja. Kedua yaitu pembahasan secara akurat terhadap kehidupan aktual yang sedang berkembang dalam segala aspeknya; ekonomi, politik, budaya, dan lain sebagainya.

Kenyataan kehidupan aktual suatu masyarakat atau bangsa memiliki corak tertentu yang bersifat situasional dan kondisional. Oleh karena itu tanpa pencermatan situasi dan kondisi aktual akan cenderung kepada upaya pemaksaan prinsip-prinsip qur'ani, sedangkan yang diinginkan Fazlur Rahman bukanlah seperti itu, melainkan hanyalah "perumusan" prinsip umum al-Qur'an dalam 
konteks sosio-historis aktual, bahkan suatu prinsip tidak dapat diterapkan sebelum dirumuskan kembali.

Operasionalisasi metode double movement diantaranya yaitu penumbuhan etika al-Qur'an ke dalam konteks kontemporer. Hal ini merupakan gerakan kedua dari metode tafsir yang digagas Fazlur Rahman. Menurutnya prinsip yang dapat direduksi dari etika alQur'an adalah prinsip sosial dan ekonomi. Melalui prinsip ini, aturan lama akan dimodifikasi selaras dengan situasi kontemporer. Demikian juga dengan hal-hal yang ada dalam situasi kontemporer akan dirubah dengan prinsip-prinsip tersebut.

\section{Pendekatan Transformatif : Metode Penafsiran Masdar F. Mas'udi}

Dalam sebuah tulisannya (1988) ,'Memahami Ajaran Suci dengan Pendekatan Transformasi”, Masdar menawarkan suatu pendekatan dalam memahami ajaran agama, yang ia sebut sebagai "pendekatan transformative". Masdar memahami "transformasi" disini sebagai terjemahan dari hijriyyah, yakni suatu perpindahan dari satu posisi keposisi yang lain untuk mengejar tingkat kualitas yang lebih baik. Pendekatan itu ia jelaskan sebagai suatu pendekatan yang memandang perubahan (change) sebagai sarana untuk mencapai cita kebaikan kualitatif yang bermuara padacita Kebaikan Mutlak_-dalam bahasa agama disebut Tuhan.

Pendekatan ini diusulkan lantaran semua agama tidak pernah datang sekadar untuk membenarkan apa yang tengah menjadi "nyata" dalam kehidupan manusia, melainkan—sebagaimana terbukti dalam sejarahagama selalu datang dengan gugatan-gugatan yang mendasar mengenai makna dari "apa yang tengah menjadi kenyataan” itu.

Usulan ini dikemukakan Masdar setelah ia menyajikan dua pendekatan lain yang dikritiknya, yakni pendekatan ortodoksi, dan pendekatan realis. ${ }^{7}$ Menurut Masdar, ${ }^{8}$ secara embrional kecenderungan hlm. 286.

7 Budhy Munawar-Rachman (ed.), 1994. Kontekstualisasi Doktrin Islam dalam Sejarah. Jakarta:Paramadina, 
ortodoksi yang tekstualis dan formalistis itu bermula sejak masa-masa awal, yakni ketika beberapa sahabat, antara lain Bilal bin Abi Rabah, secara tegas menolak ijtihad Khalifah Umar dalam pembagian tanah fa'i yang dikenal sawad al-'lraq. Dalam perkembangan berikutnya, pendekatan ortodoksi ini dianut oleh Imam Syafi'i dan muridnya Ahmad Ibn Hanbal, yang memberikan otoritas kepada teks hadits secara penuh.

Kritik Masdar' terhadap pendekatan ortodoksi ini adalah ketidakbolehannya mempertanyakan validitas dan relevansi teks doktrin, lebih-lebih ayat al-Qur'an. Prinsip mereka, apabila terjadi konflik antara teks dengan realitas, maka yang dimenangkan teks. Ia lebih memilih teks dari pada jiwa teks itu sendiri.

Pendekatan realis bias dilihat pada pemikiran Mu'tazilah yang berhadapan dengan kaum ortodoks Ahmad bin Hanbal. Mereka terlalu percaya kepada nalar manusia, sehingga memaksakan melihat wahyu (ajaran) tidak boleh bertentangan dengan keputusan nalar. Akibatnya, penganut pendekatan ini terjangkiti oleh relativisme yang labil.

Kritik Masdar atas pendekatan ini adalah, pertama, kaum realis membiarkan hidup ini tanpa patokan apapun akibat paradigmanya yang selalu mengikuti kecenderungan masyarakat. Kedua, secara kualitatif orientasinya adalah status quo. Masdar melihat pendekatan realis berakar dari filsafat positivism yang digagas August Comte yang selalu mendasarkan kebenaran pada sesuatu yang empiric belaka.

Menurut Masdar, berbeda dengan pandangan ortodoksi yang memandang teks ajaran (ayat) sebagai wujud dari "ide kemutlakan", pendekatan transformative memandang teks ajaran, atau ayat, tetap sebagai ayat, yang berarti "perlambang" atau 'tanda" dari "ide kemutlakan' yang

8 Masdar. 1995. "Meletakkan Kembali Maslahat sebagai Acuan Syari'ah", Ulumul Qur'an,No.3,Vol.VI, hlm.

${ }_{9}^{9}$ Masdar. 1988. Memahami Ajaran Suci dengan Pendekatan Transformasi, dalam Iqbal Abdurrauf Saimima(ed.), Polemik Reaktualisasi AjaranIslam, Jakarta:Pustaka Panjimas. hlm. 177-178. 
dikandungnya. Dengan ungkapan lain, ayat-ayat yang terbaca dalam Kitab Suci itu pada hakekatnya adalah objektivitas atau verbalisasi (pengungkapan tersurat) terhadap ide-ide kebaikan universal yang telah ditanamkan Tuhan dalam fitrah manusia sejak awal mula ('azaliy).

Cara pandang ayat sebagai "perlambang" bagi "ide kemutlakan" membawa konsekuensi pada pemaknaan ulang terhadap ayat muhkamat dan ayat mutasyabihat, serta konsep qath'iy dan dhanny. Pendekatan transformatif mendefinisikan ayat mubkamat dan mutasyabihat bukan dari sudut verbal, bahasa, melainkan dari sudut substansi makna yang dikandungnya.

Ayat mubkamat adalah ayat yang menegaskan prinsip-prinsip yang, secara eksplisit maupun hanya implisit, diakui oleh setiap manusia demi fitrahnya sendiri sebagai manusia. Sedangkan ayat mutasyabihat apabila ia berbicara bukan mengenai prinsip itu sendiri, melainkan mengenai "teknis metodis"bagaimana prinsip-prinsip itu dilaksanakan. Dua pengertian ini sama-sama tidak mempersoalkan apakah dari sudut bahasa verbalnya bersifat tegas atau samar-samar, bersifat terus-terang atau sindiran. Dengan demikian, konsekuensinya, ayat-ayat mubkamat pastilah bersifat universal karena dalam dirinya prinsip-prinsip itu memang universal, dan dengan sendirinya tidak memerlukan ijtihad. Demikian sebaliknya untuk ayat mutasyabihat.

Adapun pendekatan transformatif dalam memahami al-Qur'an harus mengacu pada dua rumusan berikut:

a. Kemaslahatan dan keadilan sosial

Dalam tulisannya (1995) "Meletakkan Kembali Maslahat sebagai Acuan Syari'at", Masdar menjelaskan kerangka metodologi hokum yang ia gunakan dalam menetapkan suatu keputusan hukum. Perihal sumber hukum, pertama-tama, Masdar mengatakan:

"Sesungguhnyalah pendirian yang mengatakan bahwa hokum Islam, atau syari'at Islam, harus bersumber pada al-Qur'an atau 
al-hadits tidak dengan serta-merta salah. Pernyataan itu bias salah, tapi juga bias benar. Tergantung pada apa yang dimaksud dengan al-Qur'an dan hadits Nabi itu. Jika yang dimaksud dengan al-Qur'an dan hadits sebagai sumber hokum adalah ayatayat al-Qur'an dan hadits-hadits Nabiyang_-secara langsung atau tidak-mengemukakan perihal system keyakinan dan system nilai (seperti nilai keadilan, persamaan manusia didepan hukum, persaudaraan, dan sebagainya), maka pernyataan itu benar. Tetapi jika yang dimaksud sebagai dasar hokum Islam adalah ayat-ayat al-Qur'an atau hadits Nabi yang pada dasarnya ia sendiri merupakan ayat dan hadits hukum, maka pernyataan tersebut,menurutsaya, memang tidak tepat."

Untuk menguatkan pendapatnya tentang kemaslahatan dan keadilan, ia mensubstitusi prinsip ushul al-figh, sehingga tampak telah melampaui teks (beyond the texts), menjadi idza shabhat al-mashlahatu fahiya madz̧habiy (jika tuntutan kemaslahatan, keadilan, telah menjadi sahmelalui kesepakatan dalam musyawarah—maka itulah madzhabku), bukan lagi idza shahba al-hadits fahuwa madzhabi y (apabila suatu hadits (teks ajaran) telah dibuktikan kesahihannya, itulah madzhabku). Kaidah yang lebih menekankan pada substansi, yaitu kemaslahatan-keadilan, bukan berarti segi formal dan tekstual dari ketentuan hokum harus diabaikan. Ketentuan legal-formal-tekstual yang sah, bagaimanapun, harus menjadi acuan tingkah laku manusia dalam kehidupan bersama, kalau tidak ingin terjadi anarki. Tetapi pada saat yang sama, haruslah disadari sedalam-dalamnya bahwa patokan legal-formal dan tekstual hanyalah merupakan cara bagaimana cita kemaslahatan, keadilan, itu diaktualisasikan dalam kehidupan nyata. Ini berarti bahwa ketentuan formal-tekstual, yang bagaimana pun dan datang dari sumber apapun, haruslah selalu terbuka atau diyakini terbuka untuk diubah atau diperbaharui sesuai dengan tuntutan kemaslahatan dan cita keadilan. 


\section{b. Rekonstruksi qath'i dan dhanniy}

Menurut Masdar, al-Qur'an maupun al-Hadits memuat dua jenis keputusan atau ajaran yanguniversal dan partikular sekaligus. Ajaran yang bersifat universal dan mengatasi dimensi ruang dan waktu (mutlak) itulah yang disebut oleh al-Qur'an sendiri dengan istilah "muhkamat", atau meminjam bahasa ushulal-figh "qath'iy". Sementara yang bersifat juz'iyyah (partikular dan teknis-operasional), yang karenanya terkait dengan ruang dan waktu, disebut "mutasyabihat" atau "dhanny".

Dalam pengertian klasik, qath'iy adalah ajaran yang dikemukakan dalam teks bahasa yang tegas (sharib), sedangkan dhanniy adalah ajaran yang dikemukakan dalam teks bahasa yang tidak tegas, yang ambigu atau bias diartikan lebih dari satu pengertian. Konsep qath'iy-dhanniy dalam pengertian inilah, menurut Masdar, yang telah membuat pemahaman keagamaan terlalu harfiyah dan pada tingkat tertentu menjadi terlalu bersifat legal formalistik, dan pada akhirnya membuat figh kehilangan watak dinamisnya. Oleh karena itu, ajaran qath'iy, didefinisikan ulang oleh Masdar, sebagai ajaran-ajaran yang bersif atasasi yang kebenarannya dicukupkan oleh dirinya sendiri (selfevidence), diatas nama ketentuan-ketentuan normatif dan aturan-aturan hokum diletakkan. Ia bersifat pasti, tidak berubah-ubah dan karena itu bersifat fundamental, yaitu nilai kemaslahatan atau keadilan, yang notabene merupakan jiwanya hukum.

Sedangkan ajaran dhanny (hipotetik), menurut Masdar, adalah ajaran yang derajat kebenarannya tidak bersifat apriori dan aksiomatis. Kebenarannya harus didukung oleh sesuatu diluar dirinya. Masuk kategori ini adalah ajaran atau petunjuk agama baik dari al-Qur'an maupun al-Hadits yang bersifat jabaran (implementatif) dari prinsipprinsip yang mubkam atau qath'iy dan universal. Karena sifatnya sebagai 
jabaran atau terapan, maka ajaran dhanny ini bersifat nisbi, terikat oleh ruang dan waktu, oleh situasi dan kondisi.

Semua ketentuan agama yang dalam fiqh disebut sebagai ketentuan hokum (kecuali ketentuan normative tentang mana yang halal dan mana yang haram), menurut Masdar, semuanya adalah dhanny. Hukum potong tangan bagi pencuri, lempar batu bagi pezina, prosentase pembagiang ghanimah (tanah rampasan perang), prosentase pembagian waris, definisi operasional mustahiq sedekah wajib (zakat/pajak) yang delapan, dan ketentuan-ketentuan teknis lain yang bersifat non etis, masuk kategori dhanny.

Implementasi dari metode penetapan pajak itu zakat terhadap rekonstruksi makna Qath'iy dan dzanny, adalah bahwasanya pajak mesti ada tarif dan objek pajaknya, hal ini termasuk Qathi'iy, abadi selamanya sepanjang masa. Akan tetapi rincian dari tarifnya termasuk dzanny. Sebagai contoh konkret adalah mengenai objek yang wajib dizakati, Masdar Farid Mas'udi berpendapat tentang cakupan harta yang harus dizakati, harus diperluas suntuk konteks harta yangharus dizakati, harus diperluas untuk konteks sekarang. Tidak hanya pada kurma dan anggur sementara kelapa sawit, apel, kopi dan tembakau yang tidak kalah ekonomisnya dibebaskan begitu saja dari kewajiban zakat.Angka tarif pajak bersifat dzanny dan harus disesuaikan dengan kebutuhan negara, tidak boleh pegawai pajak menarik kepada wajib pajak dengan tidak ada tarifnya (seenaknya).

\section{PENAFSIRAN FAZLUR RAHMAN DAN MASDAR F. MAS'UDI TENTANG ZAKAT DAN PAJAK}

\section{Penafsiran Fazlur Rahman Zakat sebagai Pajak}

Fazlur Rahman dikenal sebagai seorang tokoh intelektual Islam modern yang ternama. Salah satu pemikirannya yaitu mengenai zakat 
dan pajak. Pada awal 1966, Fazlur Rahman menyarankan bahwa struktur perpajakan sebaiknya dirasionalkan dan diefisienkan dengan menerapkan kembali zakat, membenahi kembali tarifnya mengingat makin melambungnya anggaran belanja pemerintah, dan memperluas cakupannya kepada sektor investasi kekayaan sehingga dapat memperbaiki motivasi Islamipara pembayar pajak dan meminimalkan pengelakan pembayaran pajak yaitu dengan membayar zakat yang bebannya sedikit (Fazlur Rahman, 2000 : 49).

Penafsiran Fazlur Rahman tentang distribusi zakat yang terdapat pada QS. at-Taubah ayat 60 yang berbunyi:

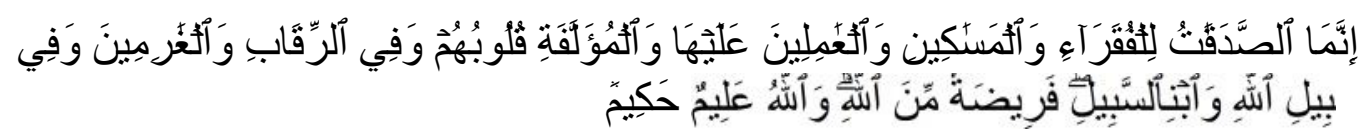

"Sesungguhnya zakat-zakat itu, hanyalah untuk orang-orang fakir, orang-orang miskin, pengurus-pengurus zakat, para mu'allaf yang dibujuk hatinya, untuk (memerdekakan) budak, orang-orang yang berhutang, untuk jalan Allah dan untuk mereka yuang sedang dalam perjalanan, sebagai suatu ketetapan yang diwajibkan Allah, dan Allah Maha Mengetahui lagi Maha Bijaksana.”

Ayat di atas merupakan merupakan pengejawantahan salah satu prinsip keadilan sosial dan ekonomi dalam QS. al-Hasyr: 7 yang berbunyi:

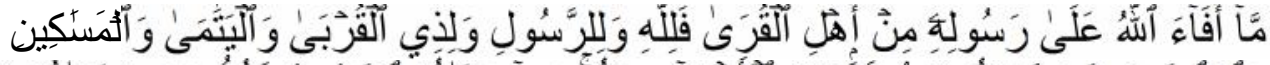

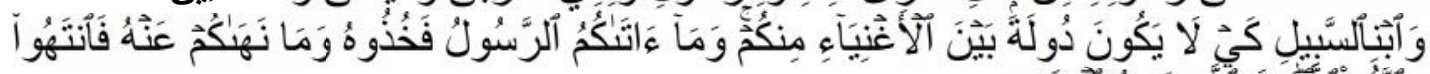

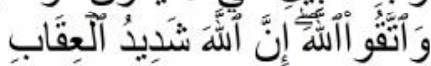

"Apa saja harta rampasan (fai-i) yang diberikan Allah kepada RasulNya (dari harta benda) yang berasal dari penduduk kota-kota maka adalah untuk Allah, untuk Rasul, kaum kerabat, anak-anak yatim, 
orang-orang miskin dan orang-orang yang dalam perjalanan, supaya harta itu jangan beredar di antara orang-orang kaya saja di antara kamu. Apa yang diberikan Rasul kepadamu, maka terimalah. Dan apa yang dilarangnya bagimu, maka tinggalkanlah. Dan bertakwalah kepada Allah. Sesungguhnya Allah amat keras hukumannya."

Kedua ayat di atas menunjukkan bahwa kekayaan tidak boleh beredar hanya dikalangan orang-orang kaya. Fazlur Rahman berpandangan bahwa kesejahteraan sosial diisyaratkan oleh ayat tersebut meliputi membantu orang-orang yang terjerat hutang, gaji pegawai administratif (kolektor pajak), pengeluaran diplomasi (untuk menarik hati orang-orang ke dalam islam), pertahanan, pendidikan, komunikasi dan kesehatan (Fazlur Rahaman, 1995 : 60-61).

Lebih jauh lagi Fazlur Rahman (1976 : 29) menyatakan bahwa:

Zakat was the only permanent tax envisaged by the qur'an and the prophet, that the statement of the items of itsexpenditure in the qur'an is so comprehensive that, for that period, it contains all the areas of public expenditures from defense through communications (welfare of the "wayfarers" as the Qur'an has it), to social welfare, and that, therefore, the muslims might consider adjusting somewhat the zakat-rate and the basis of its collection to modern needs.

Perlu adanya langkah penyesuaian (readjustment) tarif zakat selaras dengan kebutuhan kontemporer yang dapat diaplikasikan sebagai pengganti pajak-pajak sekuler di negara-negara Islam. Ini sekaligus akan memberi motivasi religius kepada para wajib pajak (Taufik Adnan Amal, 1989 : 218).

Menurut Fazlur Rahman pada saat itu cakupan zakat disalah pahami, zakat dipahami sebagai pajak kekayaan yang dikenakan terhadap kekayaan seseorang yang tertimbun dan merupakan surplus (tidak terhadap pendapatan tahunan sebagaimana pendapat beberapa penulis). Khususnya 
dalam periode modern, zakat lantas murni menjadi santunan yang bersifat sukrela, sedang kedudukannya yang dulu diganti oleh pajak sekuler yang datang dari negara modern. Fazlur Rahman sangat menyayangkan sikap ulama yang menolak langkah penyesuaian tarif zakat dengan dalih apabila zakat tidak dapat memenuhi kebutuhan masyarakat Islam, pemerintah dapat menetapkan pajak lainnya. Penetapan pajak-pajak yang tidak islami ini, bagi Fazlur Rahman merupakan esensi sekularisme.

Di sisi lain, menurutnya, zakat adalah pajak satu-satunya yang ditetapkan al-Qur'an, seperti dalam pernyataanya (1970: 327):

"A slightly different but fundamentally the same intellectual approach is illustrated by the question of zakat, the only tax imposed by the Qur'an Its expenditure items are so multifariousinculding defense, communications, education (according to Qur'an commentators) and even diplomatic."

Maksud dari pernyataan di atas bahwa zakat masih disalahpahami sebagaishadaqah yaitu pemberian untuk orang miskin. Dalam perkembangan ekonomi yang maju lembaga zakat yang semula dirumuskan dalam suasana ekonomi masyarakat yang belum berkembang haruslah dipandang sebagai pungutan atas setiap pertambahan nilai kekayaan (tidak dipahami bahwa zakat merupakan pungutan suka rela per tahun).

Kesimpulan dari penafsirannya adalah pertama, Sistem distribusi zakat harus diperluas sehinggamencakup sektor investasi kekayaan dan seluruh aspek pembiayaan negara. Sistem distribusi zakat diperluas dimaksudkan agar zakat tidak dipahami hanya sebagai sumbangan sukarela. Selain itu, dimaksudkan agar peran zakat itu maksimal dan posisi zakat tidak tergeser dan tidak diambil alih oleh pajak sekuler pada sebuah 
negara modern. Kedua zakat sebagai pajak, artinya:sistem perpajakan harus dimasukkan ke dalam naungan zakat dengan mengubah strukturnya karena hanya zakat yang ditetapkan sebagai pajak dalam al-Qur'an. Salah satu tujuannnya adalah menegakkan prinsip keadilan sosial dan ekonomi yang merangkum seluruh aktivitas negara. Kesejahteraan yang hakiki adalah untuk kesejahteraan bersama dalam sebuah negara.

\section{Penafsiran Masdar F.Mas'udi tentang Penyatuan Zakat dan Pajak}

Pemikiran Masdar Farid Mas'udi tentang zakat dan pajak, sebenarnya mempunyai hubungan dalam konsep keagamaan (kerohanian) dan konsep keduniawian (kelembagaan). Zakat dan pajak bukanlah hubungan dualisme yang dikotomis, melainkan hubungan keesaan wujud dialektis.Menurutnya, zakat merasuk ke dalam pajak sebagai ruh dan jiwanya, sedangkan pajak memberi bentuk pada zakat sebagai badan atau raga bagi proses pengejawantahan (Mujamil Qomar, 2002 : 2005).

Masdar meyakini bahwa zakat adalah sebuah mekanisme spiritualisasibermasyarakat melalui pintu masuk yang paling material. Sementara pintumasuk yang paling material dalam kehidupan berbangsa dan bernegara adalahpajak, karena tidak ada negara yang bisa hidup tanpa adanya pajak (Muhtar Sadili, 2003 : 172).

Berdasarkan hal tersebut, Masdar (2003 : 103) berpendapat bahwa: "Pemisahanlembaga zakat dan lembaga pajak adalah satu hal yang sesat danmenyesatkan. Karena konsep zakat merupakan konsep pajak yangharus digunakan sebesar-besarnya untuk kemakmuran rakyat, tanpamemandang agama serta suku bangsa. Pada dasarnya, hakekat membayarpajak pada saat ini sama saja dengan membayar zakat, hanya saja tidakdisadari. Oleh karena itu, setiap orang yang membayar pajak harus disertaidengan nilai membayar zakat kemudian setelah itu harus melakukan kontrol terhadap negara agar dana tersebut tidak diselewengkan". 
Perbedaan antara yang niat dan yang tidak adalah menyangkut hakdiakhirat nanti. Pembayaran pajak dengan niat zakat akan memperoleh pahalaspiritual-ukhrawi, karena dengan niat demikian itulah harapannya. Sedangkanyang tidak disertai niat maka ia tidak memperoleh hal tersebut.Niat adalah ruh, persambungannya adalah Tuhan. Sedangkan amalseperti sedekah/pajak adalah badan persambungannya dengan manusia.

Keduanya berbeda, tetapi tidak untuk dipisahkan. Oleh karena itu, sebagaimana tercermin dalam konsep zakat, harta diserahkan kepada Negara sebagai kelembagaan kepentingan manusia dalam mengatur kehidupannya. Sedangkan untuk Tuhan, cukup niat yang menjiwai dan melatar-belakangi penyerahan pajak itu saja (Mahsun Fuad, 2003 : 98).

Tawaran pemikiran ini tampaknya didasari oleh keprihatinannya membaca realitas pemikiran dan praktik zakat dikalangan umat Islam yang selama 12 abad atau bahkan lebih secara berangsur-angsur tidak dapat membebaskan umat manusia dari berbagai keterpurukan kehidupannya. Dalam pandangan Masdar, ada tiga kelemahan dasar dan sekaligus menjadi cirri pokok yang saling kait-mengait dari zakat.

Pertama, kelemahan pada segi filosofi atau epistemologinya. Kelemahan ini ditandai oleh tidak adanya pandangan social yang mendasari praktik zakat, alias dogmatis a sosial. Zakat hanya dipandang sekadar amaliah ritual yang terpisah dari konteks social apapun. Zakat hanya merupakan santunan karitatif yang bersentuhan dengan kebutuhan perorangan, dalam skala yang tentu sangat terbatas. Ini, kata Masdar, salah satunya didorong pandangan dominan umat Islam terhadap teologi dan paradigma sosialnya.

Kelemahan kedua berkaitan dengan struktur dan tata laksana zakat (kelembagaannya). Misalnya, tentang konsep zakat itu sendiri, objek zakat, atau harta yang harus dizakati, kadar zakat, waktu zakat, mashrafal-zakat, dan seterusnya. Berangkat dari pandangan keagamaan yang dogmatis itu, zakat pun kemudian dipahami secara formalistis a historis. 
Kelemahan ketiga adalah pada aspek managemen operasionalnya. Pada tingkatan ini, zakat kandas ditangan kaum feudal keagamaan (religio feodalism).

Masdar (1993) mengajukan tawaran untuk mengembalikan zakat sebagai cita agama kerakyatan. Cara yang diajukannya adalah membongkar kembali filosofi social zakat dan akar-akar sejarah zakat pada masa Rasulullah SAW. Menurutnya, padamulanya zakat itu upeti sebagaimana umumnya berlaku dalam praktik ketatanegaraan zaman dulu. Hanya saja, upeti yang secara nyata telah membikin rakyat yang miskin terus tenggelam dalam kemiskinannya, dengan spirit "zakat", lembaga upeti itu justru harus menjadi sarana yang efektif bagi pemerataan dan penyejahteraan kaum miskin. Dengan kata lain, lembaga upeti yang semula menjadi sumber kedhaliman, dengan spirit "zakat" harus ditransformasikan menjadi wahana penciptaan keadilan. Untuk itu, kata Masdar, Islam memahami bahwa "upeti" sama sekali bukan milik penguasa, melainkan milik rakyat yang dimulai justru dari gugusannya yang paling jelata. Hal ini merupakan interpretasi Masdar mengenai distribusi zakat sebagaimana termaktub dalam al-Qur'an surat at-Taubah ayat 60. Lembaga upeti itu kini diperhalus menjadi apa yang disebut dengan "pajak".

\section{PENUTUP}

Melalui metode double movement yang dirumuskan oleh Fazlur Raman menghasilkan interpetasi zakat sebagai pajak. Ia beralasan bahwa zakat hanya satusatunya pajak yang ditetapkan kepada umat Islam sebagaimana yang termaktub dalam al-Qur'an QS. at-Taubah ayat 60 dan QS, al-Hasyr ayat 7 dan sebagaimana historis pada masa dahulu. Kemudian setelah digeneralisasikan dan dicari substansi tujuan kedua ayat tersebut adalah distribusi zakat tidak hanya terbatas pada delapan golongan saja akan tetapi lebih luas lagi yaitu mencakup sektor investasi kekayaan dan seluruh aspek pembiayaan Negara untuk kesejahteraan bersama dalam 
kehidupan bernegara. Selanjutnya, ia merumuskan bahwa zakat sebagai pajak. Artinya, sistem perpajakan harus dimasukkan ke dalam naungan zakat dengan mengubah strukturnyakarena hanya zakat yang ditetapkan sebagai pajak dalam alQur'an.

Berbeda dengan Fazlur Rahman, Masdar F. Mas'udi dengan metode tafsir transformatifnya, yaitu dengan memegang kemaslahatan dan keadilan sebagai dasar dalam corak penafsirannya serta merekonstruksi konsep qath'idan dhanniy, ia berpendapat bahwa seluruh ayat yang tidak berhubungan dengan halal dan haram yang merupakan hukum qath'i yang tidak dapat ditafsirkan ulang, adalah bersifat dhanniy termasuk masalah distribusi zakat sesuai dengan QS. at-Taubah ayat 60. Maka dari itu, ia menganggap substansi zakat adalah pajak. Zakat adalah ruhnya, sedangkan pajak adalah badan atau lembaganya. Jadi, apabila seseorang meniatkan membayar zakat ketika mengeluarkan pajak, maka orang tersebut sudah dikatakan membayar zakat. Selain itu, membayar dua kewajiban bagi seorang muslim sangat memberatkan dan tidak mencerminkan nilai kemaslahatan.

Dari dua pemikiran di atas, penulis mengkompromikannya yaitu zakat dikelola oleh Negara dengan tujuan kesejahteraan dapat tercapai secara maksimal tanpa memberatkan masyarakat muslim itu sendiri. Pengelolaan zakat oleh Negara yang dimaksudkan adalah zakat dijadikan unit atau bagian yang dimasukkan dalam pajak. Sebagaimana halnya OJK di bawah naungan BI dalam pengawasan Bank, maka zakat dikelola oleh lembaga yang disahkan oleh Negara di bawah naungan lembaga pajak. Ini merupakan solusi awal tanpa merombak sistem yang sudah ada. Jadi pembayaran zakat memiliki kewajiban dan sanksi yang sama sebagaimana pajak. Hal ini berbeda dengan realita saat ini yaitu, zakat adalah sebagai pengurang kena pajak langsung. Hal ini dinilai kurang efektif dikarenakan, pertama: kurangnya kesadaran muzakki untuk membayar zakat meskipun memiliki kelebihan harta. Kedua, ketidakpercayaan muzakki kepada organisasi pengelola zakat (OPZ) karena dinilai kurang profesional. Ketiga, pengumpulan zakat hanya bersifat sunnah, sehingga tidak ada unsur pemaksaan kepada muzakki untuk membayar zakat. 
Keempat, zakat dikelola atau diwakilkan kepada OPZ dan didistribusikan sendiri oleh OPZ tanpa ada pengawasan dari pemerintah. Jadi, untuk meminimalkan kelemahan di atas, maka zakat hendaknya dikelola langsung oleh Negara sebagai bagian dari pajak. 


\section{DAFTAR PUSTAKA}

Abdurrachman Qadir, 2001. Zakat Dalam Dimensi Mahdah dan Sosial. Jakarta: Raja Grafindo Persada.

BudhyMunawar-Rachman (ed.), 1994. Kontekstualisasi Doktrin Islam dalam Sejarah. Jakarta:Paramadina.

Didin Hafidhuddin, 2002. Zakat dalam Perekonomian Modern. Jakarta:Gema Insani Press.

Farid Esack, 2000.Membebaskan yang Tertindas al-Qur'an, Liberalisme, Pluralisme. Bandung: Mizan.

Fazlur Rahman, 1970. "Islamic Modernism: It's Scope, Method and Alternatives," International Journal of Middle Eastern Studies, vol. 1. ,1976. "Some Islamic Issues in the Ayyub Khan Era", Essays on Islamic Civilization, ed. Donald P. Little, Leiden: E.J. Brill. , 1979. Toward Reformulating the Methodology of Islamic Law. International and Politic, Vol. 12. 1995. Tema Pokok al-Qur'an, Terj. Anas Mahyuddin, Bandung:

Penerbit Pustaka. ,2000. Cita-Cita Islam, Yogyakarta: Pustaka Pelajar.

Ilham B. Saenong, 2002.Hermeneutika Pembebasan Metodologi Tafsir Al-Qur'an menurut Hassan Hanafi. Jakarta Selatan: TERAJU.

Mahsun Fuad, 2003. Hukum Islam Indonesia, dari Nalar Partisipatoris Hingga Emansipatoris. Yogyakarta: LKiS.

Muhtar Sadili ed., 2003.Problematika Zakat Kontemporer. Jakarta: Forum zakat (FOZ). Mujamil Qomar, 2002.NU Liberal dari Tradisionalisme Ablussunnab ke Universalisme Islam Bandung: Mizan, Cet. I.

Masdar F. Mas'udi,1987. Islam Modern Tantangan Pembaharuan Islam. Terj. Rusdi Karim dan Hamid Basyaib. Jakarta: Salahuddin Press. 
, 1988. Memahami Ajaran Suci dengan Pendekatan Transformasi,

dalam Iqbal Abdurrauf Saimima(ed.), Polemik Reaktualisasi AjaranIslam, Jakarta:Pustaka Panjimas.

, 1993. Agama Keadilan, Risalah Zakat (Pajak) dalam Islam.

Jakarta:PustakaFirdaus.

, 1995. "Meletakkan Kembali Maslahat sebagai Acuan Syari'ah",

Ulumul Qur'an,No.3,Vol.VI.

, 2003. Zakat dan Keadilan Sosial, dalam M. Imdadun

Rahmat(et.al), Islam Pribumi Mendialogkan Agama Membaca Realitas, Jakarta: Erlangga.

- Bagaimana Memahami Ajaran Islam? Sebuah Tawaran Metodologis.

Makalah Tidak Diterbitkan.

Nuruddin Mhd. Ali, 2006. Zakat Sebagai Instrument dalam Kebijakan Fiskal. Jakarta:

PT Raja Grafindo Persada.

Pajak,http://id.m.wikipedia.org/wiki/pajak?_e_pi_=7\%2CPAGE_ID10\%2C5887 210405, diakses pada tanggal 05 Desember 2017.

Refky Fielnanda,. "Zakat Saham Dalam Sistem Ekonomi Islam (Kajian Atas Pemikiran Yusuf Qardhawi)." Al-Tijary: Jurnal Ekonomi dan Bisnis Islam 3.1 (2018): 57-67.

Taufik Adnan Amal, 1989. Islam dan Tantangan Modernitas (Studi atas Pemikiran Hukum Fazlur Rahman). Bandung: Mizan. 